\title{
Functional oligomers, telechelics, graft- and star-shaped poly(2,6-dimethyl-1,4-phenylene ether)s prepared by redistribution
}

\section{Citation for published version (APA):}

Aert, van, H. A. M., Burkard, M. E. M., Jansen, J. F. G. A., Genderen, van, M. H. P., Meijer, E. W., Oevering, H., \& Werumeus Buning, G. H. (1995). Functional oligomers, telechelics, graft- and star-shaped poly(2,6-dimethyl1,4-phenylene ether)s prepared by redistribution. Macromolecules, 28(23), 7967-7969. https://doi.org/10.1021/ma00127a056

DOI:

10.1021/ma00127a056

Document status and date:

Published: 01/01/1995

\section{Document Version:}

Publisher's PDF, also known as Version of Record (includes final page, issue and volume numbers)

\section{Please check the document version of this publication:}

- A submitted manuscript is the version of the article upon submission and before peer-review. There can be important differences between the submitted version and the official published version of record. People interested in the research are advised to contact the author for the final version of the publication, or visit the DOI to the publisher's website.

- The final author version and the galley proof are versions of the publication after peer review.

- The final published version features the final layout of the paper including the volume, issue and page numbers.

Link to publication

\footnotetext{
General rights

- You may freely distribute the URL identifying the publication in the public portal. follow below link for the End User Agreement:

www.tue.nl/taverne

\section{Take down policy}

If you believe that this document breaches copyright please contact us at:

openaccess@tue.nl

providing details and we will investigate your claim.
}

Copyright and moral rights for the publications made accessible in the public portal are retained by the authors and/or other copyright owners and it is a condition of accessing publications that users recognise and abide by the legal requirements associated with these rights.

- Users may download and print one copy of any publication from the public portal for the purpose of private study or research.

- You may not further distribute the material or use it for any profit-making activity or commercial gain

If the publication is distributed under the terms of Article 25fa of the Dutch Copyright Act, indicated by the "Taverne" license above, please 
Functional Oligomers, Telechelics, and Graft and Star-Shaped

Poly(2,6-dimethyl-1,4-phenylene ether)s Prepared by Redistribution

Huub A. M. van Aert, Milko E. M. Burkard, Johan F. G. A. Jansen, Marcel H. P. van Genderen, and E. W. Meijer*

Laboratory of Organic Chemistry, Eindhoven University of Technology, P.O. Box 513, 5600 MB Eindhoven, The Netherlands

\section{Henk Oevering and Gerard H. Werumeus Buning}

DSM Research, P.O. Box 18, 6160 MD Geleen, The Netherlands

Received June 6, 1995

Revised Manuscript Received September 18, 1995

The conventional synthesis of poly(2,6-dimethyl-1,4phenylene ether) (PPE) is based on the oxidative coupling polymerization of 2,6-dimethylphenol as discovered by Hay. ${ }^{1}$ Mechanistic studies have revealed that this polymerization is catalyzed by a copper-amine complex via either radicals or ionic species. ${ }^{2}$ Concurrently with the polymer-forming $\mathrm{C}-\mathrm{O}$ coupling, a redistribution takes place, which can be regarded as a transetherification of phenols and phenolic ethers. In contrast to the oxidative coupling, only a few reports deal with the mechanism of redistribution. Recently, Heitz showed that the competition of polymerization and redistribution is operative under normal conditions in the copolymerization of tetramethyl-Bisphenol acetone and 2,6-dimethylphenol. ${ }^{3}$ Earlier, Bolon and Cooper reported on the redistribution of phenol dimers under the influence of free-radical initiators or a copper catalyst. ${ }^{4}$ Based on this free-radical redistribution reaction, low molecular weight hydroxyarylene ethers are prepared when phenols are brought into reaction with PPE in the presence of a suitable initiator. ${ }^{5}$ Compounds such as $3,3^{\prime}, 5,5^{\prime}$-tetramethyl-4,4'-diphenoquinone (TMDPQ), tert-butyl perbenzoate, and benzoyl peroxide are active initiators. Via this technique, several PPE/epoxy laminates could be prepared. ${ }^{6} \mathrm{~A}$ phase-transfer-catalyzed (PTC) depolymerization by a radical-anion mechanism in the presence of either $2,4,6$ trimethylphenol or 4-tert-butyl-2,6-dimethylphenol is described by Percec ${ }^{7}$ using commercially available PPE. However, the polymers thus obtained show a bimodal molecular weight distribution, possibly due to the presence of Manich bases. ${ }^{5 a, 8}$ In this paper we present the depolymerization of $\mathrm{PPE}$ by the redistribution with functional phenols or multifunctional phenols without the use of radical initiators. The polymers prepared via this transetherification are well-defined and have a monomodal molecular weight distribution. Employing different phenols, a wide variety of functional polymer systems can be synthesized, including telechelics and graft and star-shaped polymers.

The experiments presented here were triggered by the observation that upon the addition of 4-tert-butyl2,6-dimethylphenol (TBDMP) $4.55 \mathrm{~g}, 25.5 \mathrm{mmol}$ ) to PPE (10.0 g, $M_{\mathrm{n}}=3500,83.17 \mathrm{mmol}$ of dimethylphenol repeating units, made by precipitation polymerization $\left.^{9}\right)$ at room temperature in toluene $(100 \mathrm{~mL})$ using a Pyrex glass vessel, the latter is depolymerized to low molecular weight oligomers $\left(M_{\mathrm{n}}=650\right)$. TBDMP is consumed and is incorporated as the tail unit in the oligomeric product as observed by ${ }^{1} \mathrm{H}-\mathrm{NMR}$ spectros-
Table 1. Monitoring Reaction by ${ }^{1} \mathrm{H}-\mathrm{NMR}$ Spectroscopy

\begin{tabular}{ccc}
\hline reacn time $(\mathrm{h})$ & TBDMP conv $(\%)$ & $(\overline{\mathrm{DP}})^{a}$ \\
\hline 0 & 0 & 29.1 \\
1 & 28 & 9.1 \\
24 & 35 & 5.4 \\
144 & 60 & 4.3 \\
192 & 66 & 3.8 \\
336 & 70 & 4.2
\end{tabular}

a $\overline{\mathrm{DP}}(\mathrm{PPE})$ corresponds to the degree of polymerization as determined from the ratio of the peak integrals of the repeating units and end group.

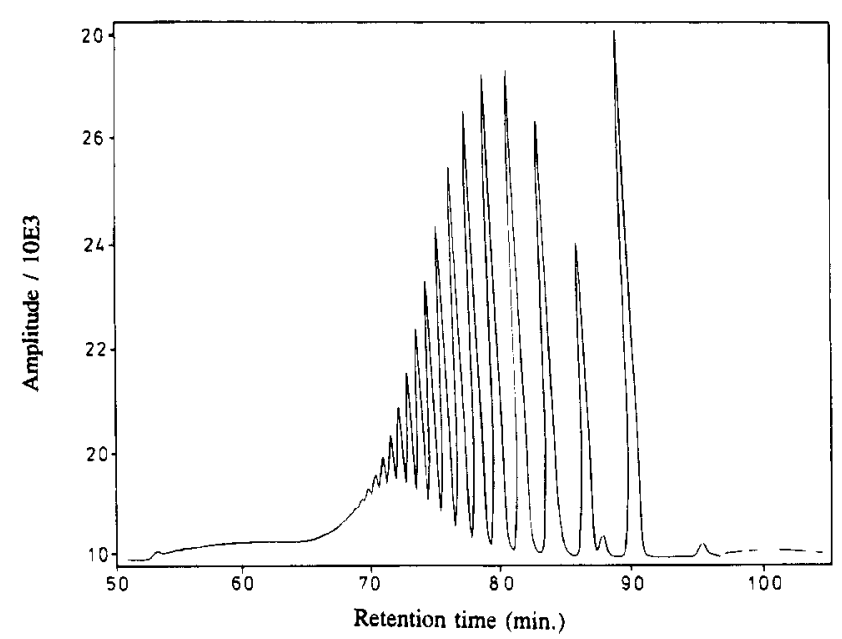

Figure 1. GPC oligomers from PPE redistribution with TBDMP.

copy. The TBDMP conversion and average degree of polymerization $(\overline{\mathrm{DP}})$ of the PPE are monitored during the redistribution by means of ${ }^{1} \mathrm{H}-\mathrm{NMR}$ spectroscopy, and the results are presented in Table 1. Figure 1 shows the GPC chromatogram (THF, $40^{\circ} \mathrm{C}$, columns 3 $\times 100 \AA$ and $5 \times 500 \AA$ type PL Gel $5,210 \mathrm{~nm}$ UV-vis detector) of oligomers prepared after a reaction time of 14 days. HPLC and ${ }^{1}$ H-NMR spectroscopy show the presence of mainly oligomers with a TBDMP tail unit and almost no oligomers $(<5 \%)$ with a 2,6-dimethylphenoxy tail unit. These results can be explained by a slow redistribution reaction without polymerization. By adding the polymerization catalyst $\mathrm{CuCl} / 4$-(dimethylamino)pyridine (DMAP), we could increase the reaction rate of the redistribution reaction significantly, especially when oxygen is present. However, in that case the well-known oxidative polymerization and some illdefined oxidative side reactions ${ }^{10}$ occur as well. However, using oxygen-free conditions, we were able to obtain clean redistribution reactions with a reasonable rate, but without oxidation. If these oxygen-free conditions cannot be met, then less basic ligands with the catalyst $\left(\mathrm{Cu}\left(\mathrm{NO}_{3}\right)_{2} \cdot 3 \mathrm{H}_{2} \mathrm{O} / \mathrm{N}\right.$-methylimidazole (NMI) or crown ethers) should be used to suppress/avoid the oxidative polymerization during the redistribution. This is in agreement with the mechanistic studies of Challa, Reedijk, and co-workers, reporting on the requirement of a phenolate as an intermediate in the coppercatalyzed oxidative polymerization. ${ }^{11}$ Besides the type of ligand, also the ligand/copper $(\mathrm{L} / \mathrm{Cu})$ ratio is of interest. ${ }^{12}$ Most appropriate reaction conditions are performed with the catalyst system $\mathrm{CuCl} / \mathrm{DMAP}, \mathrm{L} / \mathrm{Cu}$ ratio $\sim 1.6$ with exclusion of oxygen, or $\mathrm{Cu}\left(\mathrm{NO}_{3}\right)_{2} \cdot 3 \mathrm{H}_{2} \mathrm{O} /$ NMI, L/Cu ratio $\sim 10$ under ambient conditions.

In order to study the scope and limitations of this redistribution reaction without oxidation, several mono- 
Table 2. Examples of PPE Depolymerization

\begin{tabular}{lccc}
\hline added phenol & $\begin{array}{c}M_{\mathrm{n}}(\mathrm{PPE}) \\
\text { begin }\end{array}$ & $\begin{array}{c}\text { PPE repeating } \\
\text { units/phenol } \\
\text { ratio }\end{array}$ & $\begin{array}{c}M_{\mathrm{n}} \\
\text { precipitated } \\
\text { product }^{a}\end{array}$ \\
\hline $\begin{array}{c}\text { 2,6-dimethyl-4-tert- } \\
\text { butylphenol }\end{array}$ & 3500 & 9.5 & 1400 \\
4-tert-butylphenol & 11200 & 10 & 1910 \\
4-tert-butylphenol & 11200 & 15 & 2400 \\
2,6-dimethylphenol & 11200 & 1.8 & 2810
\end{tabular}

a Molecular weights belonging to the polymer fraction insoluble in methanol; the low molecular weight fraction is soluble in methanol. Molecular weights are determined using ${ }^{1} \mathrm{H}-\mathrm{NMR}$ spectroscopy.

functional phenols were brought into reaction with PPE in a good solvent. Some examples of PPE depolymerization are summarized in Table 2. Reaction time depends on reaction conditions and the phenol employed. The reaction rate is strongly influenced by the nature of the substituent of the phenol: generally phenols with electron-donating substituents show high reaction rates, whereas phenols with electron-withdrawing groups, like cyano, or steric bulky ortho substituents, like tert-butyl, are unreactive. The following parasubstituted monofunctional phenols are simply introduced as a polymer tail unit: 4-tert-butyl-2,6-dimethylphenol, 4-tert-butylphenol, 4-methoxyphenol, 4-phenylphenol, 4-chlorophenol, 4-acetamidophenol, 4-(hydroxypropyl)-2,6-dimethylphenol, 4-allyl-2,6-dimethylphenol. Para-unsubstituted phenols employed in the redistribution are 2,6-dimethylphenol and the dimer 4-(2,' 6 'dimethylphenoxy)-2,6-dimethylphenol. The redistribution is monitored by ${ }^{1} \mathrm{H}-\mathrm{NMR}$ spectroscopy. The protons in the tail or head units differ from those of the repeating unit, which is reflected by different chemical shifts, especially in the aromatic region. Moreover, not only the first and last repeating units are detected separately, but in the case of redistribution with orthounsubstituted phenols also the penultimate tail repeating unit is usually observed. These spectra show sharp peaks and the aromatic $\mathrm{C}-\mathrm{H}$ peaks of the polymer head unit are clearly detectable, contrary to similar polymers synthesized by a PTC method. ${ }^{7}$ Therefore, the polymer seems to be extremely pure without any ortho-methyl group oxidation. This is confirmed by ${ }^{13} \mathrm{C}-\mathrm{NMR}$ spectroscopy (no peaks at 114.5 and $132.5 \mathrm{ppm}$ ) and FTIR spectroscopy (no absorption at $1645 \mathrm{~cm}^{-1}$ ). Although the disproportionation in the redistribution mechanism should give rise to two types of oligomers, oligomers with a substituted tail unit and oligomers with an unsubstituted 2,6-dimethylphenoxy tail unit, almost no oligomers are present with an unsubstituted tail unit as observed by HPLC and ${ }^{1} \mathrm{H}-\mathrm{NMR}$ spectroscopy. This suggests that some $\mathrm{C}-\mathrm{O}$ coupling must occur.

The use of multifunctional phenols in this clean and convenient redistribution opens the pathway to the synthesis of numerous multifunctional PPE's. Bifunctional phenols are introduced into the polymer, resulting in telechelic polymers with two hydroxyl chain end functionalities, polymers that are of interest as precursors for block copolymers or polymer networks. The following bisphenols are employed: 2,2-bis(4-hydroxy3,5-dimethylphenyl)propane (tetramethyl-Bisphenol acetone) (TMBPA), 4,4'-isopropylidenediphenol (Bisphenol acetone) (BPA), bis (4-hydroxy-3,5-dimethylphenyl)methane (tetramethyl-Bisphenol formaldehyde) (TMBPF), bis(4-hydroxyphenyl)methane (Bisphenol formaldehyde) (BPF). As an example the $400 \mathrm{MHz}^{1} \mathrm{H}-\mathrm{NMR}$ spectrum of a telechelic polymer with a TMBPA core is

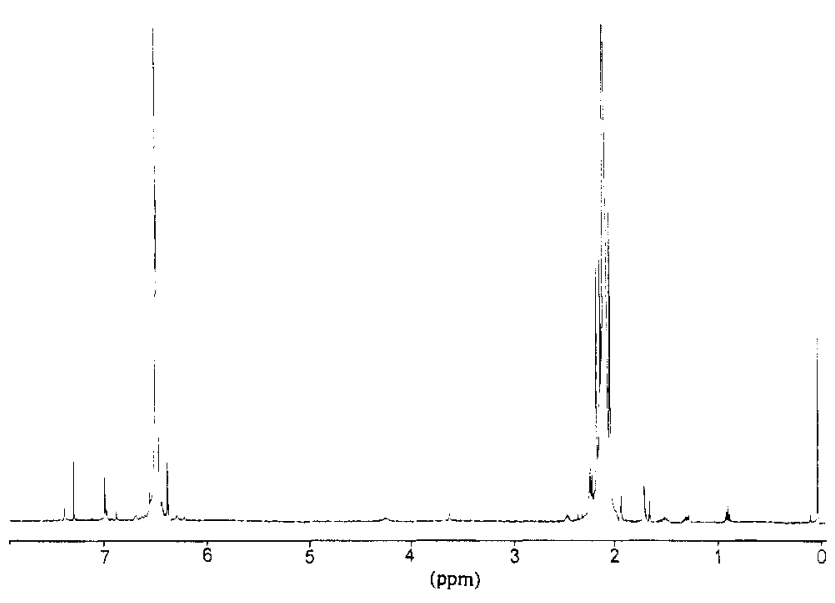

Figure 2. ${ }^{1} \mathrm{H}-\mathrm{NMR}$ spectrum of telechelic polymers with a TMBPA core; preparation by reacting $0.16 \mathrm{~g}$ of TMBPA, 3.41 $\mathrm{g}$ of PPE $\left(M_{\mathrm{n}}=11200\right), 0.14 \mathrm{~g}$ of DMAP, and $0.07 \mathrm{~g}$ of CuCl in $30 \mathrm{~mL}$ of chloroform under argon. After $9 \mathrm{~h}$ of reaction time, extraction with EDTA(aq). (10\%), $\mathrm{HCl}(\mathrm{aq})$. (10\%), $\mathrm{NaOH}(\mathrm{aq})$. (10\%), and evaporation of the chloroform, a telechelic polymer was isolated. Peak assignments are described by Risse ${ }^{13 b}$ and Nava. ${ }^{13 \mathrm{~d}}$

Chart 1. PPE Star-Shaped Polymer with a 64-Functional Dendritic Core

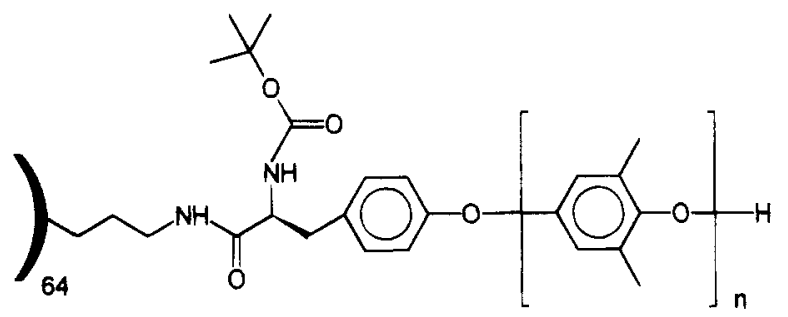

shown in Figure 2. Although GPC shows a complete conversion of PPE into bifunctional telechelics, NMR spectroscopy indicates that the bisphenolic distributing agent is not built-in statistically. A significant portion of the bisphenol is found at the tail end, leading to a telechelic with two different end groups. Any explanations for this behavior are speculative at this time. Telechelic polymers have been prepared by the copolymerization of DMP with, e.g., TMBPA as well; 13 however, besides the copolymerization, also substantial DMP homopolymerization takes place. Pure telechelic polymers are only obtained after redistribution. ${ }^{3}$

The versatility of the redistribution is shown by synthesizing graft copolymers or star-shaped polymers. In a first approach, we used tert-butyl calix $[n]$ arenes as a core with $n=4$ and 8. Due to intramolecular hydrogen bonding in $n=4$ we were not able to obtain well-defined structures from calix[4]arene. The redistribution in the case of calix[8]arene yields an eightarmed star polymer. All spectroscopic data indicate that here all phenols of the calix[8]arene have reacted. When poly ( $p$-hydroxystyrene) is used for redistribution with PPE in THF, a graft copolymer is prepared with a polystyrene backbone and poly(2,6-dimethyl-1,4-phenylene ether) side chains. Star-shaped polymers with a dendritic core are of great interest and are prepared from PPE redistribution with $N$-tert-Boc-protected tyrosine modified poly(propylene imine) dendrimers (Chart 1). ${ }^{14}$ The arm length of the star-shaped polymers is determined by the molar ratio of PPE repeating units and tyrosine end groups. The number of arms is determined by the generation of dendrimer (i.e., 4,8 , 16,32 , or 64 end groups) or by a 64 end group dendrimer 


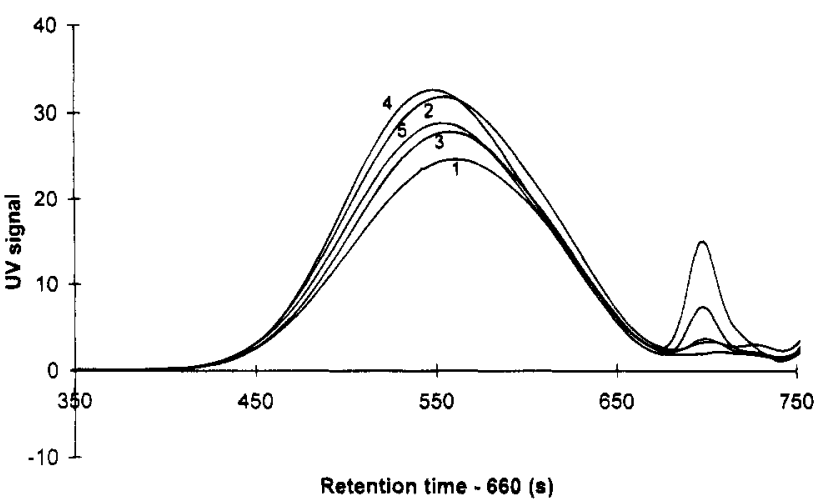

Figure 3. SEC star-shaped polymers prepared from different generations of dendrimer with the same estimated average arm length (22.5 units) using THF as eluents. The numbers 1-5 are indicative for the dendrimer generation (4-64 end groups).

Table 3. Dynamic Light Scaterring Data

\begin{tabular}{cccc}
\hline $\begin{array}{c}\text { dendrimer } \\
\text { generation }\end{array}$ & $\begin{array}{c}\text { estd no. of } \\
\text { PPE arms }\end{array}$ & $\overline{\mathrm{DP}}$ & $R_{\mathrm{H}}(\mathrm{nm})$ \\
\hline $5^{a}$ & 0 & 0 & 2.1 \\
$5^{b}$ & 12.8 & 22.5 & 2.4 \\
$5^{b}$ & 32 & 22.5 & 3.4 \\
$5^{b}$ & 51.2 & 22.5 & 4.0 \\
$5^{c}$ & 64 & 22.5 & 5.7 \\
$4^{c}$ & 32 & 22.5 & 4.2 \\
$2^{c}$ & 8 & 22.5 & 3.7
\end{tabular}

a Dendrimer $100 \%$ modified with phenylalanine end groups. ${ }^{b}$ Tdendrimer core modified with phenylalanine/tyrosine mixture. $c$ Dendrimer core modified with tyrosine.

which is modified with a statistical mixture of tyrosine and phenylalanine. All star-shaped polymers show divergent physical properties in comparison with the linear analogues as observed by dynamic light scattering and size exclusion chromatography by implementing an on-line viscometer. ${ }^{15}$ Figure 3 shows the SEC chromatograms using a UV detector $\left(\mathrm{THF}, 40^{\circ} \mathrm{C}\right.$, columns $2 \times$ Shodex KF 80-M, $254 \mathrm{~nm} \mathrm{UV} \mathrm{detector)} \mathrm{and}$ polymers with the same estimated average arm length but with a different number of arms show the same hydrodynamic volume. However, dynamic light scattering (DLS) measurements in THF (Table 3) (ALV/SP. 86 goniometer, Spectra Physics series $2000 \mathrm{Ar}^{+}$laser $(514.5 \mathrm{~nm}, 300 \mathrm{~mW})$ ) show that the hydrodynamic radius increases with the number of arms. This increase is proposed to be caused by a restricted mobility of the arms at high number of arms and/or generation, which is expressed in the hydrodynamic radius as measured with DLS but not in the hydrodynamic volume as measured by SEC.

In conclusion, a general synthetic technique for multifunctional poly(phenylene ether)s has been described. Oxidative polymerization and redistribution are disconnected by tuning the reaction conditions. Chain length and end group functionality can be varied easily.

Acknowledgment. We thank Ellen de Brabander, Abdellatif Moussaïd, Giovanna di Pietro, Prof. J. Joos- ten, Christian Widdershoven, Wieb Kingma, Joop Vorenkamp, Patrick Baesjou, Prof. J. Reedijk, and Prof. G. Challa for experimental help and/or stimulating discussions.

\section{References and Notes}

(1) (a) Hay, A. S.; Blanchard, H. S.; Endres, G. F.; Eutace, J. W J. Am. Chem. Soc. 1959, 81, 6335. (b) Hay, A. S. J. Polym. Sci. 1962, 58,581 .

(2) (a) Percec, V.; Wang, J. H.; Clough, R. S. Makromol. Chem. Macromol. Symp. 1992, 54/55, 275. (b) Viersen, F. J. Ph.D. Thesis, State University of Groningen, The Netherlands, 1988. (c) Viersen, F. J.; Renkema, J.; Challa, G.; Reedijk, J. J. Polym. Sci., Polym. Chem. Ed. 1992, 30,901.

(3) Heitz, W. Angew. Makromol. Chem. 1994, 223, 135.

(4) (a) Bolon, D. A. J. Org. Chem. 1967, 32, 1584. (b) Cooper, G. D.; Gilbert, A. R.; Finkbeiner, H. Polym. Prepr. (Am. Chem. Soc., Div. Polym. Chem.) 1966, 7, 166.

(5) (a) White, D. M. J. Org. Chem. 1969, 34, 297. (b) White, D. M. J. Polym. Sci., Part A 1971, 9, 663.

(6) Chao, H. S.-I.; Whalen, J. M. React. Polym. 1991, 15, 9. (b) Chao, H. S.-I.; Whalen, J. M. J. Appl. Polym. Sci. 1993, 49, 1537.

(7) (a) Percec, V.; Wang, J. H. Polym. Bull. 1990, 24, 63. (b) Percec, V.; Wang, J. H. Polym. Bull. 1990, 24, 71. (c) Wang, J. H.; Percec, V. Polym. Bull. 1991, 25, 25.

(8) White, D. M.; Nye, S. A. Macromolecules 1990, 23, 1318.

(9) van Aert, H. A. M.; Venderbosch, R. W.; van Genderen, M. H. P.; Lemstra, P.J.; Meijer, E. W. J. Macromol. Sci., Pure Appl. Chem. 1995, A32, 515 .

(10) (a) Usami, T.; Kogawa, Y.; Takayama, S.; Koyama, T. Eur Polym. J. 1990, 26, 699. (b) Pickett, J. E. Polym. Degrad. Stab. 1994, 44, 119.

(11) (a) Viersen, F. J.; Challa, G.; Reedijk, J. Recl. Trav. Chim. Pays-Bas 1989, 108, 247. (b) Viersen, F. J.; Challa, G.; Reedijk, J. Polymer 1990, 31, 1361. (c) Viersen, F. J.: Challa, G.; Reedijk, J. Polymer 1990, 31, 1368. (d) Tullemans, A H. J.; Bouwman, E.; de Graaff, R. A. G.; Driessen, W. L.; Reedijk, J. Recl. Trav. Chim. Pays-Bas 1990, 109, 70. (e) Challa, G.; Chen, W. Makromol. Chem., Macromol. Symp. 1992, 59, 59. (f) Chen, W.; Challa, G.; Reedijk, J. Polym. Commun. 1991, 32, 518

(12) Redistribution rates are higher at low $\mathrm{L} / \mathrm{Cu}$ ratios but give rise to the forming of $3,3^{\prime}, 5,5^{\prime}$-tetramethyl-4, $4^{\prime}$-phenoquinone (TMDPQ) by the $\mathrm{C}-\mathrm{C}$ quinone coupling of 2,6-dimethylphenol, especially for ligands like $N$-methylimidazole and 18-crown-6. This $\mathrm{C}-\mathrm{C}$ coupling is avoided by using high $\mathrm{L} / \mathrm{Cu}$ ratios or shorter reaction times. These results are in good agreement with: Viersen, F. J.; Challa, G.; Reedijk, J. Recl. Trav. Chim. Pays-Bas 1990, 109, 97

(13) Koch, W.; Risse, W.; Freitag, D. Macromol. Chem. 1985, 12 , 105. (b) Risse, W.; Heitz, W.; Freitag, D.; Bottenbruch, L. Makromol. Chem. 1985, 186, 1835. (c) Chen, W.: Challa, G.; Reedijk, J. Polym. Commun. 1991, 32, 518. (d) Nava, H.; Percec, V. J. Polym. Sci., Polym. Chem. Ed. 1986, 24, 986. (e) Wang, J. H.; Percec, V. Polym. Bull. 1991, 25, 25.

(14) (a) de Brabander-van den Berg, E. M. M.; Meijer, E. W. Angew. Chem. 1993, 105, 1370; Angew. Chem., Int. Ed. Engl. 1993, 32, 1308. (b) Jansen, J. F. G. A.; de Brabander-van den Berg, E. M. M.; Meijer, E. W. Science 1994, 266, 1226. (c) Jansen, J. F. G. A.; Peerlings, H. W. I., de Brabandervan den Berg, E. M. M.; Meijer, E. W. Angew. Chem., Int. Ed. Engl. 1995, 34, 1206 .

(15) Star polymers with the same dendritic core but an increasing number of PPE arms of the same estimated length show a lower refractive index increment $(\mathrm{d} n / \mathrm{d} c)$, while star polymers with same arm length prepared from different dendrimer generations show a constant $\mathrm{d} n / \mathrm{d} c$. The $\mathrm{dn} / \mathrm{dc}$ is higher for the dendritic core than for the PPE arms. Therefore, only qualitative data could be obtained using SEC implementing a viscometer and refractive index (RI) detector; further studies are under way.

MA9507913 